\title{
Resistance through art, politics, and culture
}

\author{
Lourdes Torres $^{1}$
}

Accepted: 18 January 2021 / Published online: 10 February 2021

( ) The Author(s), under exclusive licence to Springer Nature Limited part of Springer Nature 2021

After a deadly and fraught year, people looked forward to 2021 with cautious optimism. The new year, however, has had an inauspicious start. While the COVID-19 vaccines are thankfully finally being distributed, a surge of new infections has struck all over the world. Here in the US, Black Americans and Latinos continue to get sick and die in disproportionately high numbers. On January 6, as Congress met to certify the national presidential election, a violent insurrection incited by the president of the United States stormed the Capitol and temporarily interrupted the certification process as rioters mobbed the Capitol building bearing white supremacist symbols such as Confederate flags, anti-Semitic symbols, and hanging nooses (https://www. independent.co.uk/news/world/americas/us-politics/auschwitz-hoodie-nooses-confe derate-flag-capitol-riots-b1783995.html). We watched in horror and disbelief.

In the midst of much social unrest and divisiveness, and after years of white supremacist actions and words emanating from across the nation including from its leadership, we hear calls for reconciliation, the wringing of hands, and claims that "this is not who we are." But anyone who has studied our nation's history understands that the principles of white supremacy and nativist thinking have been, in Ibram X. Kendi's words, "stamped from the beginning" of the founding of this country and have marked its entire history. If the actions of January 6 tell us anything, it is that we must all stay engaged in the daily struggle to keep our communities safe and to work toward enacting a truly inclusive multiracial democracy—an ideal that is not guaranteed and that every one of us must consistently do our best to make a reality.

While not directly responding to our current moment, the articles in this issue engage with strategies of resistance against myriad forms of domination and cultural amnesia through art, politics, and culture. They are a testament to the resiliency and creativity of Latinx thinkers, artists, and communities who struggle to take a stand and insist that their voices be heard.

We open this issue with a remembrance of Anani Dzidzienyo, renowned scholar and educator and a foundational builder of the field of Afro-Latin American/Latinx studies.

Lourdes Torres

ltorres@depaul.edu

1 DePaul University, Chicago, USA

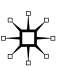


In our lead article, Álvaro Ibarra considers the drive toward self-expression by those locked away and forgotten. He invites us to explore paño art produced by Texas inmates in the 1990s. Paño art consists of drawings on cotton handkerchiefs produced by incarcerated Latinos. Though only fifteen-by-fifteen inches in size, the pieces are a testimony of the prisoners' humanity and their yearning for self-expression. Even as they endure dehumanization and isolation, they convey powerful messages of love and resistance in their art. Museums and galleries are beginning to exhibit paños, and Ibarra's essay is an invitation for scholars to pay more attention to these powerful drawings as part of the tradition of Chicano and Tejano cultural art forms. Crucial, in this challenge, is the call for scholars not only to recognize the brilliance of the art but also to recognize its producers as skillful artists.

José M. Aguilar-Hernández, Corina Benavides López, and Rebecca Gutierrez Keeton remind us of the power and promise of student activism to demand change and build institutions. They chronicle the process by which Chicana/o and Latina/o student agitation led to the establishment of the César E. Chávez Center for Higher Education at Cal Poly Pomona in the 1990s. Influenced by progressive politics and social movement mobilizations across the state, students took action to address a lack of culturally relevant campus spaces and incidents of racism at their university, and succeeded in establishing innovative cultural sites. Through an analysis of oral histories of students, administrators, and faculty involved in this struggle, the authors demonstrate the power students have when they mobilize strategically to create the kinds of spaces they need to support and enhance their education.

Brenda Nicolas expands the scholarship on critical Latinx indigeneities in her study of how Zapotecs in Los Angeles build community across generations and geographical spaces. Analyzing the oral histories shared by Zoochina Zapotecs in LA, she focuses on how, through cultural practices, specifically via participating in traditional dances and Oaxacan brass bands, the children of Indigenous migrants participate in fortifying their connection to indigeneity and their transnational homelands. These unique spaces of intergenerational sharing become generative sites of shared belonging and transmission of Zapotec cultural forms and practices.

Regina Marie Mills looks at processes of healing and growth in novels by Dominican American writers. Much of the Dominican literary archive centers the regime of Rafael Trujillo and its destructive nature as well as opposition to it, whereas Mills foregrounds narratives that elevate women's strategies for transformation. She highlights women characters' strategies for growth including "art, quiet, secrecy, surrender, and interiority." Through an incisive analysis of Angie Cruz's Soledad and Naima Coster's Halsey Street, the article demonstrates that while these art forms tend to be dismissed as feminine practices, they are in fact productive and dynamic tools that activate resistance and healing.

It is well known that in addition to promoting good health, participation in sport has other benefits, such as improving young people's self-esteem and helping them develop positive relationships. Jen McGovern's contribution encourages us to consider the importance of sport for the development of strong and healthy Latinx youth. McGovern's research examines the various factors that explain why Latinx youth do not participate in sports as much as do other ethnoracial groups. She finds that both gender and class impact participation and that girls more closely connected 
to Latinx culture are less likely to play sports. These insights will hopefully help us work to encourage all Latinx youth, especially girls, to participate in sports and reap the long-term benefits of such activity.

In this issue, we also share a vivencia by Erika Busse-Cárdenas focused on nationalism and cultural spectacles. Highlighting the performance of Peruvian culture in the New York City Hispanic Day Parade, she argues that parade participants are compelled to perform nationalistic, idealized versions of their culture that fail to capture the heterogeneous nature of identity. Such performances, she reminds us, should be contextualized within the current reality of extreme xenophobia that renders immigrants as threats.

Stay safe, stay engaged, and enjoy!

Publisher's Note Springer Nature remains neutral with regard to jurisdictional claims in published maps and institutional affiliations. 